\title{
Perbandingan Ketepatan Estimasi Bobot Badan Jantan dan Betina Pada Sapi Bali (Bos sondaicus) Menggunakan Metoda Perhitungan Winter dan Schoorl
}

\section{Comparison of Accuracy of Estimated Body Weight of Males and Females in Balinese Cows (Bos sondaicus) using Winter and Schoorl Calculation Methods}

\author{
L. Meidina, A. Jaelani*, dan M. I. Zakir \\ Program Studi Peternakan, Fakultas Pertanian, Universitas Islam Kalimantan \\ Muhammad Arsyad Al Banjari Banjarmasin, Jl. Adhyaksa No. 2 Kayu Tangi Banjarmasin 70123 \\ *Corresponding E-mail: jaelaniborneo@gmail.com \\ (Diterima: 15 November 2020; Disetujui: 25 Januari 2021)
}

\begin{abstract}
ABSTRAK
Penelitian ini bertujuan untuk menganalisis metoda perhitungan yang tepat dalam mengestimasi bobot badan sapi Bali jantan dan betina dewasa, dengan metoda perhitungan Schoorl dan Winter, menganalisis persamaan regresi antara bobot badan dengan panjang badan dan lingkar dada, serta menganalisis nilai koefisien korelasinya pada sapi Bali jantan dan betina dewasa. Pada Penelitian ini digunakan sapi Bali jantan dan sapi Bali betina masing-masing sebanyak 40 ekor, dengan umur berkisar 2 hingga 3 tahun. Metode Survai dengan menggunakan teknik purposive sampling digunakan dalam peneitian ini. Data dianalisis menggunakan uji t berpasangan, dan dihitung korelasi antara panjang badan dan lingkar dada terhadap bobot badan, dan mengetahui persamaan regresinya. Berdasarkan hasil penelitian diperoleh bahwa estimasi bobot badan pada sapi Bali jantan dan betina dewasa akan lebih akurat jika menggunakan metoda perhitungan Winter yakni dengan rata- rata persentase penyimpangan sebesar 2,9\% pada sapi Bali jantan dewasa dan 3,9\% pada sapi Bali betina dewasa. Adapun dengan menggunakan rumus Schoorl, ratarata penyimpangan cukup tinggi yakni $19,9 \%$ pada sapi Bali jantan dan $26,5 \%$ pada sapi betina. Nilai koefisien korelasi (r) ukuran lingkar dada dengan bobot badan sapi Bali Jantan dewasa memiliki korelasi yang sangat kuat (erat) yakni 0,88 dengan persamaan regresi yaitu $\hat{Y}=-374,5+4,03 x$. Adapun perolehan hasil koefisien korelasi (r) panjang badan dengan bobot badan pada sapi Bali betina memiliki hubungan yang sangat rendah yakni 0,20 dengan persamaan regresi yaitu $\hat{\mathrm{Y}}=122,2+1,2161 \mathrm{x}$.
\end{abstract}

Kata kunci: estimasi bobot badan, Winter, Schoorl, sapi Bali

\section{ABSTRACT}

This study aims to analyze the methods for accurately estimating the bodyweight of Bali bulls and adult females, and using the calculation methods of Schoorl and Winter to analyze the regression equation between body weight and body length, and bust circumference, and to analyze the correlation coefficient values in adult males and females Bali cattle. In this study, up to 40 Balinese bulls and female Balinese cattle were used each, ranging in age from 2 to 3 years old. This research adopts the survey method of purposive sampling technique. Use paired t-test to analyze the data, calculate the correlation between body length and chest circumference, and weight, and find the regression equation. According to the study results, if the Winter calculation method is used, the estimated weight of adult male and female Bali cattle will be more accurate. The average percentage deviation of adult Bali bulls is $2.9 \%$, and the average percentage deviation of adult Bali males and females is 3.9\%. As for the Shore formula, the average deviation is very high, 19.9\% for Bali bulls and $26.5 \%$ for heifers. The correlation coefficient (r) between bust size and adult Bali bull weight has a robust correlation (close) of 0.88 , and the regression equation is $-374.5+4.03 x$. The correlation coefficient ( $r$ ) between the body length and weight of female Bali cattle has a shallow relationship with the regression equation of 0.20 , which is $=122.2+1.2161 x$.

Keywords: estimated body weight, Winter, Schoorl, Balinese cattle 


\section{PENDAHULUAN}

Sapi Bali merupakan hewan asli Indonesia hasil domestikasi hewan banteng dan memiliki keunggulan pertumbuhan yang cepat, mudah beradaptasi dengan lingkungan, serta tinggi kemampuan reproduksinya.

Informasi mengenai bobot badan sangat bermanfaat terutama dalam manajemen ternak khususnya sapi pedaging. Pembeli maupun penjual sapi sebaiknya mengetahui bobot badan sapi untuk mengurangi ketidakpastian dan kerugian pada saat proses jual beli. Suatu hal yang menyulitkan apabila setiap jual beli harus menyediakan timbangan untuk sapi, selain menyulitkan pengangkutan juga tidak efisien. Selain itu juga apabila pembeli sapi selalu menghadirkan belantik (tukang taksir bobot sapi), maka perlu ada tambahan biaya yang harus dikeluarkan untuk membayar belantik tersebut. Karenanya penjual dan pembeli harus memiliki teknik tertentu dalam menaksir bobot badan sapi agar mengurangi kesalahan dalam perhitungan bobot badan.

Untuk mengetahui produktivitas seekor ternak dilakukan dengan mengetahui bobot badan, yang nilainya bisa diestimasi menggunakan ukuran tubuh sapi yang meliputi panjang badan, tinggi badan, lingkar dada, lebar punggung maupun kelangkang, panjang kelangkang dan lebar pada tulang tapis.

Pada awalnya estimasi bobot badan yang menggunakan perhitungan Schoorl maupun Winter dilakukan pada sapi-sapi Eropa yang memiliki bobot badan yang besar yakni di atas $500 \mathrm{~kg}$. Sementara sapi-sapi di Indonesia umumnya memiliki berat 250$300 \mathrm{~kg}$. Dalam perhitungan estimasi bobot badan dapat dilakukan dengan mengukur tinggi dan panjang badan, serta lingkar dada.

Pendugaan bobot badan ini untuk memudahkan dan mengurangi kesalahan dalam menentukan bobot badan sapi. Menurut Soenarjo (1998), tingkat penyimpangan Rumus Winter dibandingkan dengan penimbangan berkisar $2-6 \%$. Hanya saja dari kedua rumus tadi apakah untuk semua bangsa sapi maupun jenis kelamin sapi bisa digunakan dengan hasil yang akurat. Ataukah salah satu rumus tersebut lebih tepat untuk sapi lokal Indonesia seperti sapi Bali. Untuk itu perlu diuji tingkat akurasinya dengan cara membandingkan antara bobot badan riil hasil penimbangan dengan nilai pendugaan bobot badan dari kedua rumus Schrool maupun Winter.

Tujuan Penelitian ini adalah menganalisis 2 jenis rumus pendugaan bobot badan (Schrool dan Winter) yang memiliki tingkat akurasi tertinggi pada pendugaan bobot badan sapi Bali jantan maupun betina. Hipotesisnya adalah ketepatan estimasi bobot badan sapi Bali menggunakan perhitungan Winter lebih akurat dibandingkan dengan menggunakan perhitungan Schrool.

\section{METODE}

\section{Materi dan Alat}

Pada penelitian ini digunakan sapi Bali jantan dewasa dan sapi Bali betina dewasa masing-masing sebanyak 40 ekor dengan umur 2 sampai 3 tahun yang diperoleh dari Pasar Hewan Sarang Halang Kecamatan Pelaihari. Peralatan yang digunakan adalah: timbangan digital berkel max. 2 ton, pita ukur Haufner, dan tongkat ukur.

\section{Tempat dan Waktu Penelitian}

Penelitian dilakukan di UPT Pasar Ternak Sarang Halang Kecamatan Pelaihari Kabupaten Tanah Laut selama bulan Agustus - Oktober 2019.

\section{Metode Penelitian}

Pada penelitian ini digunakan metode Survey dengan teknik purposive sampling atau pengambilan obyek didasarkan kriteria yang sudah ditentukan yaitu Sapi Bali jantan dan betina yang berumur antara 2 sampai 3 tahun. Pengambilan data bobot badan diperoleh dengan pengukuran langsung pada ternak, dengan menggunakan ukuran tubuh (lingkar dada diukur menggunakan pita ukur Haufner 
dan pengukuran panjang badan menggunakan tongkat ukur) serta bobot badan menggunakan timbangan berkel digital.

Perlakuan menggunakan sapi Bali jantan dan betina dewasa dengan rumus pengukuran berbeda sebagai berikut:

JS = Pendugaan BB sapi Bali jantan dengan menggunakan rumus Schoorl

JW = Pendugaan BB sapi Bali jantan dengan menggunakan rumus Winter

BS = Pendugaan BB sapi Bali betina dengan menggunakan rumus Schoorl

$\mathrm{BW}=$ Pendugaan $\mathrm{BB}$ sapi Bali betina dengan menggunakan rumus Winter

\section{Parameter yang diukur}

1. Pengukuran lingkar dada $(\mathrm{cm})$ dan panjang badan $(\mathrm{cm})$ yang dimasukkan dalam rumus:

Rumus Schoorl $(\mathrm{kg})=\frac{\left(\mathrm{LD}_{\mathrm{cm}}+22\right)^{2}}{100}$

Rumus Winter $(\mathrm{kg})=\frac{(\mathrm{LD})^{2}{ }_{(\mathrm{cm})} \mathrm{x} \mathrm{PB}_{(\mathrm{cm})}}{10815,15}$ 10815,15

Keterangan: $\mathrm{LD}=$ Lingkar dada $(\mathrm{cm})$ $\mathrm{PB}=$ Panjang Badan $(\mathrm{cm})$

2. Bobot badan $(\mathrm{kg})$ dengan penimbangan, menggunakan timbangan berkel

3. Persentase (\%) penyimpangan pendugaan bobot badan $(\mathrm{kg})$ dengan hasil penimbangan $(\mathrm{kg})$, diperoleh dengan menggunakan rumus:

$\%$ Penyimpangan $=$ BB hasil penimbangan $(\mathrm{kg}) \times 100 \%$ $\mathrm{BB}$ hasil pendugaan

Analisis regresi digunakan untuk menganalisis keeratan hubungan antara dua variabel atau lebih. Dalam analisis regresi terdapat variabel bebas dan variabel tidak bebas. Data hasil penelitian dihitung untuk mengetahui korelasi antara variabel bebas (X) seperti ukuran panjang badan dan lingkar dada terhadap bobot badan sapi (Sampurna dan Suatha, 2010).

\section{Analisis Data}

Data yang didapatkan dari hasil analisis variabel yang diukur, kemudian dilakukan analisis uji t berpasangan, koefisien korelasi dan persamaan regresi (Walpole,1993).

\section{HASIL DAN PEMBAHASAN}

\section{Ukuran Lingkar Dada dan Panjang Badan Sapi Bali Dewasa}

Berdasarkan pengukuran lingkar dada pada sapi Bali jantan 171,0 cm dan sapi Bali betina 156,0 cm (Tabel 1). Nilai lingkar dada sapi Bali jantan lebih besar dibandingkan sapi Bali Betina. Demikian juga halnya dengan panjang badan sapi Bali jantan yaitu 116,8 $\mathrm{cm}$ dan ukuran panjang badan sapi Bali betina 107,4 $\mathrm{cm}$. Panjang badan sapi Bali jantan ukurannya lebih panjang dibanding Bali betina. Hal ini sejalan dengan yang dikemukakan Santosa (2008), yakni ternak jantan memiliki pertumbuhan yang relatif lebih cepat dibanding dengan betina, hal ini berarti pada umur yang sama, ternak jantan memiliki bobot badan dan daging yang lebih tinggi dibanding betina.

Aberle et al. (2001) mengemukakan bahwa ukuran tubuh seperti panjang badan

Tabel 1. Ukuran Lingkar Dada (cm) dan Panjang Badan (cm) Sapi Bali

\begin{tabular}{lcc}
\hline Variabel & Hasil Pengukuran & Koefisien Keragaman $(\%)$ \\
\hline Lingkar dada $(\mathrm{cm})$ & Sapi Bali jantan & \\
Panjang badan $(\mathrm{cm})$ & $171,0 \pm 13,18$ & 6,72 \\
\hline & $116,8 \pm 7,66$ & \\
\hline Lingkar dada $(\mathrm{cm})$ & Sapi Bali betina & 4,72 \\
Panjang badan $(\mathrm{cm})$ & $156,0 \pm 7,36$ & 3,81 \\
\hline
\end{tabular}


Tabel 2. Nilai Koefisien Korelasi Antara Bobot Badan dengan ukuran lingkar dada dan panjang Badan Sapi Bali

\begin{tabular}{llcc}
\hline Perbandingan & Ukuran Tubuh & Nilai korelasi (r) & Keterangan \\
\hline BB Sapi Bali jantan & Lingkar dada & 0,88 & Sangat erat \\
& Panjang badan & 0,56 & Sedang \\
BB Sapi Bali betina & Lingkar dada & 0,54 & Sedang \\
& Panjang badan & 0,20 & Sangat Rendah \\
\hline
\end{tabular}

Sumber: Data diolah tahun 2019

dan lingkar dada mengikuti pola pertumbuhan sewaktu kecepatan pertumbuhan mendekati konstan, kemiringan kurva laju pertumbuhan tidak berubah. Hal ini disebabkan pertumbuhan tulang, otot, dan organ-organ tubuh yang penting mulai berhenti, namun proses penggemukkan tubuh mulai dipercepat. Pada Penelitian ini, ukuran lingkar dada dan panjang badan diperoleh hasil kecepatan laju pertumbuhan atau perkembangan yang bervariasi (Salamena, 2006). Ukuran lingkar dada selalu menjadi variabel penentu dan parameter utama bobot setiap estimasi bobot badan (Sampurna dan Suatha, 2010). Hal ini disebabkan ukuran lingkar dada memiliki nilai (r) korelasi yang positif terhadap nilai bobot badan. Adapun nilai koefisien korelasinya $>$ 0,8 pada jantan dan $>0,54$ pada betina. Hal ini berarti bahwa korelasinya sangat kuat (erat) sehingga parameter lingkar dada ini dijadikan parameter utama baik pada rumus Schrool maupun rumus Winter.

\section{Analisis Korelasi Antara Ukuran Lingkar Dada dan Panjang Badan Terhadap Bobot Badan Sapi Bali}

Hasil perhitungan koefisien korelasi, diperoleh nilai keeratan hubungan antara variabel panjang badan dan lingkar dada terhadap bobot badan sapi Bali jantan dan betina (Tabel 2). Adapun pedoman untuk memberikan interpretasi serta analisis bagi koefisien korelasi mengacu pada Sugiyono (2007) adalah untuk nilai $\mathrm{r}=0,00-0,199$ menunjukan hasil korelasi yang sangat rendah, nilai $r=0,20-0,399$ menunjukan nilai korelasi yang rendah, nilai $r=0,40-0,599$ menunjukan nilai korelasi yang sedang, nilai $r=0,60-0,79$ menunjukan nilai korelasi yang kuat (erat), dan nilai $\mathrm{r}=0,80-1,000$ menunjukan nilai korelasi yang sangat kuat (erat).

Terdapat korelasi yang sangat erat antara ukuran lingkar dada dengan bobot badan pada sapi Bali jantan yaitu yang mencapai 0,88 (sangat erat) dan 0,54 (sedang) pada sapi Bali Betina (Tabel 2). Adapun koefisien korelasi berat badan dengan panjang badan adalah 0,54 (sedang) untuk sapi Bali jantan dan 0,2 (sangat rendah) untuk sapi Bali betina. Penelitian ini sejalan dengan penelitian Hamdani (2017) yang menunjukan nilai korelasi tertinggi ditunjukkan antara bobot badan dengan lingkar dada pada Sapi Krui Jantan. Adapun berdasarkan hasil penelitian Gunawan dan Putera (2016) untuk ukuran linier tubuh lebar dada, lingkar dada, panjang badan, dan tinggi pundak, berkorelasi positif dengan nilai bobot badan pada sapi Peranakan Ongole (PO).

Berdasarkan hasil penelitian Sampurna dan Suatha (2010), nilai korelasi tinggi didapatkan dari ukuran lingkar dada dengan ukuran-ukuran tubuh lainnya, sehingga disebutkan bahwa ukuran lingkar dada dapat dimanfaatkan sebagai salah satu kriteria seleksi dalam pemilihan calon bibit unggul sapi Bali baik pada jantan maupun betina. Lebih jauh Sampurna dan Suatha (2010) menyatakan bahwa ukuran lingkar dada merupakan variabel yang nilai koefisien korelasinya tertinggi terhadap bobot badan.

\section{Perbandingan Antara Bobot Badan Aktual dan Hasil Estimasi Menggunakan Rumus Schoorl dan Rumus Winter}

Nilai bobot badan hasil penimbangan pada sapi Bali Jantan berkisar antara 225,7$446,0 \mathrm{~kg}$ dengan rata-rata bobot badan 
Tabel 3. Data Bobot Badan Aktual (kg) dan Bobot Badan (kg) Hasil Estimasi Menggunakan Rumus Schoorl dan Rumus Winter pada Sapi Bali Jantan dan Betina

\begin{tabular}{lcccccc}
\hline \multirow{2}{*}{ Nilai } & \multicolumn{3}{c}{ BB Sapi Bali Jantan } & \multicolumn{3}{c}{ BB Sapi Bali Betina } \\
\cline { 2 - 6 } & Aktual & Schoorl JS & Winter JW & Aktual & Schoorl BS & Winter BW \\
\hline \multirow{2}{*}{ Minimal (kg) } & $225,70 \pm$ & $295,84 \pm$ & $224,68 \pm$ & $196,80 \pm$ & $262,44 \pm$ & $199,35 \pm$ \\
& 8,72 & 9,18 & 7,16 & 6,38 & 8,36 & 5,22 \\
Maksimal (kg) & $446,00 \pm$ & $462,25 \pm$ & $412,43 \pm$ & $356,90 \pm$ & $368,64 \pm$ & $286,97 \pm$ \\
& 19,68 & 21,47 & 26,18 & 17,28 & 14,59 & 7,53 \\
Rata-rata (kg) & $315,80^{\mathrm{B}} \pm$ & $374,28^{\mathrm{A}} \pm$ & $319,21^{\mathrm{B}} \pm$ & $252,84^{\mathrm{b}} \pm$ & $317,19^{\mathrm{a}} \pm$ & $242,32^{\mathrm{b}} \pm$ \\
Simpangan Baku & 16,5 & 17,26 & 16,13 & 13,5 & 15,78 & 9,84 \\
(kg) & 60,51 & 52,62 & 65,84 & 25,49 & 26,07 & 26,98 \\
Koefisien Variasi & 19,16 & 14,06 & 20,62 & 10,08 & 8,22 & 11,13 \\
(\%) & & & & & & \\
\hline
\end{tabular}

Keterangan: Setiap angka yang diikuti huruf superscript yang berbeda menyatakan hasil berbeda nyata $(p>0,05)$

sebesar 315,8 $\pm 60,51 \mathrm{~kg}$ dan nilai koefisien variasinya sebesar 19,16\% (Tabel 3). Adapun bobot badan hasil penimbangan pada sapi Bali betina berkisar antara $196,8-356,9 \mathrm{~kg}$ dengan rataan bobot badan sebesar 252,84 \pm $25,49 \mathrm{~kg}$ dan nilai koefisien variasinya sebesar $10,08 \%$.

Bobot badan sapi Bali jantan yang diperoleh dari pendugaan berdasarkan rumus Schoorl berkisar 295,84 - 462,25 kg dengan memiliki rata-rata berat badan sebesar $374,28 \pm$ $52,62 \mathrm{~kg}$ dan nilai koefisien variasinya sebesar $14,06 \%$. Adapun bobot badan sapi Bali Betina hasil pendugaan menggunakan rumus Schrool berkisar 262,44 - 368,64 kg dengan memiliki rataan bobot badan sebesar 317,19 $\pm 26,07 \mathrm{~kg}$ dan koefisien variasi sebesar 8,22\%.

Adapun bobot badan hasil pendugaan berdasarkan rumus Winter sapi Bali Jantan berkisar 224,68 - 412,43 kg dengan memiliki rataan bobot badan sebesar 319,21 $\pm 65,84$ $\mathrm{kg}$ dan koefisien variasi sebesar 20,62\%. Adapun bobot badan sapi Bali Betina berkisar 199,35 - 286,97 kg dengan memiliki rata-rata berat badan sebesar 242,32 $\pm 26,98 \mathrm{~kg}$ dan koefisien variasi sebesar $11,13 \%$.

Berdasarkan hasil analisis uji $t$ berpasangan menunjukkan bahwa bobot badan sapi Bali jantan hasil penimbangan berbeda nyata $(\mathrm{P}<0,05)$, dengan bobot badan sapi Bali jantan hasil pendugaan dengan menggunakan rumus Schoorl. Namun bobot badan sapi Bali jantan hasil penimbangan, tidak berbeda nyata $(\mathrm{P}>0,05)$ dengan bobot badan hasil pendugaan menggunakan perhitungan rumus Winter.

Bobot badan pada sapi Bali betina hasil penimbangan tidak berbeda nyata $(\mathrm{P}>0,05)$, dengan bobot badan sapi Bali betina hasil pendugaan mengggunakan Rumus Winter, namun terjadi perbedaan yang nyata $(\mathrm{P}<0,05)$ dengan rataan bobot badan sapi Bali betina hasil pendugaan menggunakan rumus Schrool.

Riyanto dan Purbowati (2009), menyatakan bahwa pertambahan bobot badan sapi ditentukan oleh berbagai faktor seperti jenis kelamin, jenis sapi, pakan yang diberikan, umur, dan manajemen dalam pemeliharaannya. Menurut Sumadi (2008), ukuran-ukuran tubuh akan menggambarkan suatu kemampuan dan tampilan yang baik dari produksi seekor ternak serta memberi tampilan bentuk tubuh yang menunjukan ciri khas bangsa sapi tertentu. Ukuran tubuh selain dapat digunakan untuk menaksir bobot badan akan tetapi bisa juga untuk menaksir bobot karkas (Erfan, 2004). Adapun ukuran tubuh yang digunakan yaitu: dalam dada, lebar dada, lingkar dada, panjang badan, tinggi gumba, dan indeks kepala.

Dalam pendugaan bobot badan menggunakan rumus Winter berdasarkan pada dua parameter yaitu lingkar dada dan 
Tabel 4. Persentase Penyimpangan Bobot Badan Hasil Estimasi (\%) Menggunakan Rumus Schoorl dan Rumus Winter Terhadap Nilai Bobot Badan Aktual sapi Bali

\begin{tabular}{llcccc}
\hline \multirow{2}{*}{ No. } & \multirow{2}{*}{ Penyimpangan } & \multicolumn{2}{c}{ Sapi Bali Jantan } & \multicolumn{2}{c}{ Sapi Bali Betina } \\
\cline { 3 - 6 } & & Schoorl & Winter & Schoorl & Winter \\
& JS & JW & BS & BW \\
\hline 1. & Minimal (\%) & $5,0 \pm 0,03$ & $0,4 \pm 0,01$ & $9,2 \pm 0,04$ & $0,7 \pm 0,01$ \\
2. & Maksimal (\%) & $35,9 \pm 0,16$ & $21,3 \pm 0,18$ & $44,4 \pm 0,22$ & $31,4 \pm 0,17$ \\
3. & Rata-rata Penyimpangan (\%) & $19,9^{\mathrm{A}} \pm 0,02$ & $2,9^{\mathrm{B}} \pm 0,01$ & $26,5^{\mathrm{a}} \pm 0,03$ & $3,9^{\mathrm{b}} \pm 0,02$ \\
\hline
\end{tabular}

Keterangan: Setiap angka yang diikuti huruf superscript besar pada kolom sapi Bali jantan dan huruf superscript kecil pada kolom sapi Bali betina yang berbeda menyatakan hasil yang berbeda nyata $(\mathrm{p}>0,05)$

panjang badan. Sementara rumus Schrool menggunakan parameter lingkar dada saja. Nilai hasil pendugaan yang didasarkan pada parameter yang lebih banyak dan memiliki koefisien korelasi yang tinggi akan mendapatkan nilai pendugaan yang lebih akurat, dibandingkan dengan yang hanya menggunakan satu parameter. Hal ini karena parameter satu dan lainnya terlebih yang memiliki koefisien korelasi positif akan saling memperkuat.

\section{Persentase Penyimpangan Bobot Badan Hasil Pendugaan Terhadap Bobot Badan Aktual Pada Sapi Bali}

Untuk pendugaan bobot badan tidak selamanya sama persis dengan nilai aktual, ada kalanya ternjadi ketidaktepatan atau penyimpangan, namun tetap yang lebih diterima adalah yang penyimpangannya paling kecil. Penyimpangan diantara bobot badan aktual (hasil penimbangan) dengan bobot badan yang diperoleh dari pendugaan hasil perhitungan metoda Schoorl pada sapi Bali jantan, memiliki besaran penyimpangan sebesar $5,0 \%-35,9 \%$ dengan rata-rata penyimpangan $19,9 \%$ dan besaran penyimpangan pada sapi Bali betina berkisar $9,2 \%$ - 44,4\% dengan rata-rata penyimpangan $26,5 \%$ (Tabel 4). Adapun besaran penyimpangan diantara bobot badan hasil penimbangan dengan bobot badan hasil pendugaan dengan metoda Winter pada sapi Bali jantan sebesar 0,4\% - 21,3\% dengan rata-rata penyimpangan $2,9 \%$ dan besaran penyimpangan pada sapi Bali betina sebesar
$0,7 \%-31,4 \%$ dengan rata-rata penyimpangan $3,9 \%$.

Rataan simpangan pendugaan bobot badan menggunakan perhitungan metoda Winter lebih kecil dikarenakan perhitungan Winter menggunakan 2 parameter yang memiliki nilai koefisien korelasi yang sangat dekat. Untuk Lingkar dada koefisien korelasinya 0,88 (sangat tinggi) dan panjang badan nilai koefisien korelasinya 0,54 (tinggi), sehingga saling menguatkan. Berbeda halnya dengan rumus Schrool yang hanya menggunakan 1 parameter yakni lingkar dada. Memang nilai koefisien korelasi lingkar dada terhadap bobot badan sangat tinggi, namun apabila digunakan dengan parameter yang lebih banyak yang juga memiliki nilai korelasi yang sangat tinggi terhadap bobot badan, maka hal ini akan lebih menguatkan.

Dari hasil penelitian yang didapatkan, diperoleh persentase penyimpangan rumus Winter lebih rendah dibandingkan dengan rumus Schrool. Hal ini berarti pendugaan bobot badan menggunakan metoda Winter pada sapi Bali, baik pada jantan maupun betina, dapat diterapkan karena memiliki hasil simpangan yang kurang dari $6 \%$. Ini sesuai dengan pernyataan Soenarjo (1998), yang menyatakan bahwa penyimpangan pendugaan bobot badan yang bisa diterima adalah yang penyimpangannya berkisar $2 \%-6 \%$. 
Tabel 5. Persamaan Regresi Antara Bobot Badan dengan Ukuran Lingkar Dada dan Panjang Badan Sapi Bali Jantan dan Betina

\begin{tabular}{lcccc}
\hline \multirow{2}{*}{ Variabel } & \multicolumn{2}{c}{ Sapi Bali Jantan } & \multicolumn{2}{c}{ Sapi Bali Betina } \\
\cline { 2 - 5 } & Persamaan & $\mathrm{r}$ & Persamaan & $\mathrm{r}$ \\
\hline Lingkar dada & $\mathrm{Y}=-374,5+4,03 \mathrm{x}$ & 0,88 & $\mathrm{Y}=-41,32+1,88 \mathrm{x}$ & 0,54 \\
Panjang badan & $\mathrm{Y}=-200,7+4,42 \mathrm{x}$ & 0,56 & $\mathrm{Y}=122,2+1,21 \mathrm{x}$ & 0,20 \\
\hline
\end{tabular}

\section{Persamaan Regresi Antara Bobot Badan Dengan Ukuran Lingkar Dada dan Panjang Badan}

Persamaan regresi antara bobot badan dengan lingkar dada pada sapi Bali jantan yaitu $\hat{\mathrm{Y}}=-374,51+4,03 \mathrm{x}$. Adapun pada sapi betina mengikuti persamaan $\mathrm{Y}=-41,32$ $+1,88 x$. (Tabel 5). Persamaan regresi antara bobot badan dengan panjang badan pada sapi jantan mengikuti persamaan regresi $Y=-200,7$ $+4,42 \mathrm{x}$. Adapun pada sapi betina mengikuti persamaan $\mathrm{Y}=122,2+1,21 \mathrm{x}$. Menurut Sudirman (2005), persamaan tersebut sesuai dengan persamaan regresi model linier yang sangat baik dan sangat tepat apabila digunakan untuk menduga nilai bobot badan pada Sapi Bali jantan. Berdasarkan hasil penelitian Gunawan dan Putra (2016), ukuran panjang badan memiliki korelasi yang positif terhadap bobot badan karena bentuk sapi yang silinder yang akan meningkat seiring peningkatan panjang badan. Peneliti lain, Niam et al. (2012) menyatakan bahwa ukuran lingkar dada dan ukuran panjang badan menunjukan suatu volume, yang dimanifestakan dalam bentuk bobot badan.

\section{KESIMPULAN DAN SARAN}

\section{Kesimpulan}

1. Estimasi bobot badan yang menggunakan perhitungan metoda Winter pada sapi Bali jantan dan betina lebih akurat penggunaannya dengan rata-rata persentase penyimpangan bobot badan sapi Bali 2,9 $\%$ pada sapi jantan dan 3,9 \% pada sapi betina. Adapun dengan menggunakan rumus Schoorl, rata-rata penyimpangan $19,9 \%$ pada Sapi Bali jantan dan 26,5 \% pada sapi Bali betina.

2. Koefisien korelasi (r) antara bobot badan dengan lingkar dada pada sapi Bali Jantan memiliki hubungan yang sangat kuat (erat) sebesar $r=0,88$ dan mengikuti persamaan regresi $\hat{Y}=-374,5+4,03 x$. Adapun koefisien korelasi (r) antara nilai bobot badan dengan panjang badan pada sapi Bali Betina memiliki hubungan yang sangat rendah dengan koefisien korelasi $r$ $=0,20$ dan mengikuti persamaan regresi $\hat{\mathrm{Y}}=122,2+1,2161 \mathrm{x}$.

\section{Saran}

Berdasarkan hasil penelitian ini, untuk estimasi nilai bobot badan pada sapi Bali baik Jantan maupun betina dewasa sebaiknya menggunakan rumus Winter.

\section{DAFTAR PUSTAKA}

Aberle, D.E., J.C. Forrest., D.F. Gerrad., and E.W. Miils. 2001. Principles of Meat Science 4th ed. W.H. Freeman and Company. San Francisco. USA.

Erfan. 2004. Karakteristik Ukuran dan Bentuk Tubuh Domba Garut dan Persilangan Domba St Croix dan Moulton Charollais. Laporan Penelitian Fakultas Peternakan. Institut Pertanian Bogor. Bogor.

Gunawan, A dan Putera, B. W. 2016. Aplikasi linier ukuran tubuh untuk seleksi fenotipik bibit induk sapi PO di Kabupaten Bojonegoro. Jurnal Ilmu Produksi dan Teknologi Hasil Peternakan, 4(3) : 375-378.

Hamdani. M. D. I, A. Husni, Sulastri, dan Renitasari. 2017. Ukuran-ukuran tubuh sapi krui jantan dan betina di kabupaten 
pesisir barat lampung. Jurnal ilmu ternak. 17(2): 99-105

Kadarsih, S. 2003. Peranan Ukuran Tubuh Terhadap Bobot Badan Sapi Bali di Provinsi Bengkulu. Jurnal Penelitian UNIB. 9(1): 45-48

Ni'am, H. U., Purnomoadi, A. dan Dartosukarno, S. 2012. Hubungan antara ukuranukuran tubuh dengan bobot badan sapi Bali betina pada berbagai kelompok umur. Animal Agriculture Journal. 1(1): 541-556.

Putra, B. W., Fuah, A. M., Nuraini, H, dan Priyanto, R. 2016. Penerapan teknik citra digital sebagai metode pengukuran morfometrik ternak pada sapi Bali dan peranakan ongole. Jurnal Ilmu Pertanian Indonesia. 21(1): 63-68

Rachma, S., R. M. T. Agus, dan L. Rahim. 2009. Penggunaan lebar kelangkang, lebar punggung, lebar tulang tapis dan panjang kelangkang untuk menduga bobot badan Sapi Bali. J. Sains \& Teknologi. 9: 119-124

Riyanto dan Purbowati, E. 2009. Panduan Lengkap Sapi Potong. Jakarta: Penebar Swadaya.

Samosir, M. H., H. Daulay, A. H. 2016. Pendugaan Bobot Badan Sapi Brahman cross, Sapi Aceh dan Sapi Bali berdasarkan panjang badan dan lingkar dada. Jurnal Peternakan Integratif. 4(2): 155-162.

Salamena, J. F. 2006. Karakteristik Fenotif
Domba Kaisar di Kabupaten Maluku Tenggara Barat Propinsi Maluku sebagai Langkah Lwal Konservasi dan Pengembangannya. Disertasi. Sekolah Pascasarjana IPB. Bogor.

Santosa, U. 2005. Tata Laksana Pemeliharaan Ternak Sapi. Penebar Swadaya. Jakarta.

Sampurna, I. P., dan I. K. Suatha. 2010. Pertumbuhan alometri dimensi panjang dan lingkar tubuh sapi Bali jantan. Jurnal veteriner. 11(1): 46-51.

Soenarjo, C. 1998. Buku Pegangan Kuliah Ilmu Tilik Ternak. CV. Baru. Jakarta.

Sugiyono. 2007. Metode Penelitian Kuantitatif Kualitatf dan R\&D. Bandung. Alfabeta

Sumadi., Supiyono., N. Ngadiyono, dan T. W. Murti. 2008. Buku Ajar Evaluasi dan Penilaian Ternak. Fakultas Peternakan Universitas Gadjah Mada. Yogyakarta.

Talib, C., K. Entwistle, A. Siregar, BudiartiTurner, and D. Lindsay. 2003. Survey of population and production dynamics of Bali cattle and existing breeding programs in Indonesia. ACIAR Proceedings. 110: 3-9.

Purwantara, B., Noor, R. R., Andersson, G. and Rodriguez-Martinez, H. 2012. Banteng and Bali Cattle in Indonesia: Status and Forecasts. Reprod Dom Anim 47 (Suppl. 1), 2-6

Walpole, R. E. 1993. Pengantar Statistik. Edisi ke-5. Gramedia Pustaka Utama, Jakarta. 